Journal Universitas Muhammadiyah Gresik Engineering, Social Science, and Health International Conference (UMGESHIC)

UMGCINMATIC : $1^{\text {st }}$ Rethinking Education during Covid-19 Era: Challange and Innovation

\title{
INSTAGRAM AS A REFERENCE FOR STUDENT BODY IMAGE
}

\author{
Author \\ Wiwid Dwi Safitri ${ }^{1}$, Muhimmatul Hasanah ${ }^{2}$ \\ Fakultas Psikologi Universitas Muhammadiyah Gresik ${ }^{1}$, Universitas Pesantren Sunan \\ Drajat $^{2}$ \\ Email: Penawiwid.waldi@gmail.com, Himmahasanah@insud.ac.id,
}

\begin{abstract}
This study aims to determine the body image of female students using Instagram at the Faculty of Psychology, University X. The popularity of social media Instagram makes female students unable to resist the development of communication technology. Instagram has become a phenomenon as one of the biggest magnets in shaping one's character by becoming a body image tool by showing various physical advantages shown through uploaded content or posts. Posting pictures about attractive physical appearances raises the ideal beauty standard which causes female students to judge themselves as less attractive than the photos/videos uploaded to the media. This study is a qualitative research with phenomenological research type, where the researcher uses 5 subjects to be interviewed. The results of this study indicate that the five subjects who have been interviewed by the researchers have a description of the specific criteria to describe the ideal body (perfect body image type) they want.
\end{abstract}

Keywords: Student, Body Image, Body Ideal 


\section{INTRODUCTION}

Women often feel dissatisfied with their body appearance. They usually have a criterion called the ideal image related to the perspective on their body appearance. Awareness of the ideal image makes women feel that they do not fit and are always lacking when compared to the ideal criteria. Physical advantages become very attractive to women, especially students. The student instills a personal image of himself about what his body looks like. A person's feelings, thoughts and perceptions of his body are referred to as body image.

Body image can be described based on how far the individual is satisfied with their physical appearance and body parts as a whole (Thompson, 2002). According to Amalia (2007), someone who has an ideal self-image in accordance with his wishes includes having an ideal body shape. The body is the most important part of physical appearance which is part of one's identity. The body can be easily seen and judged by others and even oneself with the naked eye. This condition encourages a student to have an ideal body. The incompatibility of the ideal body shape will bring dissatisfaction to the body.

Advances in communication technology today bring a lot of influence for every individual and community group. Its development is quite rapid considering that there are so many new innovations that are neatly packaged, one of the indirect communications from the social network is Instagram. The popularity of these social networks makes the public, especially female students, unable to resist the development of communication technology which is increasingly mushrooming. Instagram really spoils its users with various types of features and ease of accessing their application. Instagram is a type of photo sharing application that provides an opportunity for users to take photos, apply digital filters and share them to various social networking services, including the Instagram application itself (Martanatasha and Primadini, 2019: 159). In a survey conducted by APJII (Association of Indonesian Internet Service Providers) in 2020, there were 69.2 million Instagram users and were nominated by the productive age group, namely in the age range of 18-34 years as much as $71 \%$. Meanwhile, if the number of users is categorized by gender, there are more women (51\%) compared to male users.

Instagram has become a phenomenon that has become one of the biggest magnets in the process of forming one's character. Apart from being a communication medium, on the other hand, Instagram has a function as a body image tool, namely by showing superiority in terms of physicality, style of dress, and how to talk in communicating which will indirectly bring interest from the public through content or posts uploaded on social networks. (Nasiha, 2017: 339).

The content or post is uploaded by an influencer social media Instagram.The is called influencerSelebgram, Selebgram is a personal account owner who has many fans (followers) because the photos or videos they upload are interesting and much liked. Setiawati (2020) said that most celebgrams display their physical beauty on their Instagram content.Posting pictures of attractive physical appearances has proven to give rise to ideal beauty standards and causes female students to judge themselves as less attractive than the photos/videos of thecontent celebrity. It is 
thethat is interesting and even affects their followers Instagram, thus helping in forming the body image of those who enjoy the Instagram content.

Body Image is a discussion of a person's mental picture of the shape and size of his body. In line with the previous understanding, this discussion was studied by students of the Faculty of Psychology. Psychology Faculty students are students who study psychology. Psychology is a scientific discipline that studies the mental, mind and behavior of humans. Psychology students are among the educated people who should understand more about thephenomenon body image and view it as normal. But in reality, psychology students at University $\mathrm{X}$ have problems regarding body image and compare their bodies with what they see onsocial media Instagram.

Psychology students study a variety of psychological experiences that can be applied in their daily lives, learning and discussion of physical subjects is widely discussed in psychology student learning, ranging from developmental psychology courses which explain physical changes at each stage and many other psychological theories that relate in the discussion, including self-concept and self-confidence.

In previous studies, the results were greater as $74 \%$ of psychology students compared their bodies with other people and $26 \%$ of other students did not compare themselves. The body is the most important part of physical appearance which is part of a person's identity. The body can be easily seen and judged by others and even oneself with the naked eye. This situation encourages a student to have an ideal body shape. The ideal image which is beauty is used as a benchmark to judge a woman.

This statement is supported by research conducted by Mukhlis (2013: 5) which reveals that: the relativity of beauty in society is assessed differently between cultures and over time. Developing countries, including Indonesia, consider the ideal image for women to be harmony between body and height. This perception becomes an interesting topic for popular culture to emphasize hatred and fear of obesity.

Levine Smolak (1994) said that looking at photos of slim models can make women feel bad about their bodies, some research results show a negative impact. The media creates an image of a woman as slim and causes a number of direct negative effects including excessive attention to weight, body dissatisfaction, negative mood, and decreased perceptions of attractiveness. The ideal image created by the media makes the female students make comparisons to evaluate their appearance.

\section{RESEARCH METHODS}

This research is a qualitative research. Qualitative research is a method used to examine the status of groups of people, objects, conditions, thought patterns of groups of events in the present or a systematic, actual and accurate description of the facts, the nature of the relationship between the phenomena being investigated. The type of phenomenology in this study is used to describe 
the general meaning of a number of individuals on various life experiences related to concepts or phenomena. Phenomenon is everything that appears in human consciousness. The main purpose of this type of phenomenology is to reduce an individual's experience of a phenomenon to a description of a general subject or essence (John WC: 2015).

The subjects of this study were selected by incidental sampling. Incidental sampling is atechnique based on chance, which means any subject found by the researcher and can be used as a sample, which is deemed appropriate and suitable as a source of data by the researcher. Determination of sampling this type of data source according to researchers can provide the best information to researchers about the problems in research. Thestrategy incidental sampling used was based on criteria. sampling Criterionworks when all the individuals studied represent a society that has experienced the phenomenon (Creswell, 2015).

The criteria referred to in this study include:

1. Active Students at the Faculty of Psychology, University X.

2. Students aged $19-24$ years

3. Having Instagram Social Media for more than 1 year

4. enjoying at least 7 celebgram content (the content of the celebgram is related to physical content, such as: Beauty, fashion, culinary, and life style)

\section{DISCUSSION AND RESULT}

\section{Discussion}

\subsection{Body Image}

Body image or body image according to Arthur (2010) is a subjective thought that a person has about his or her physique, especially matters relating to other people's judgments, and how well the body must be adapted to these perceptions. Some researchers use this term for things related to physical appearance, evaluation of body function, body coordination, body movements, and so on. Burn (1993: 189) reveals that Body Image is a picture that an individual has of himself as an individual who has physicality, the physical in question is the body shape that that person has.

According to Thompson (2002), body image can be defined based on how far the individual is satisfied with his body parts and his overall physical appearance. According to Amalia (2007), a person has an ideal self-image as he desires, including having an ideal physical shape. According to him, the incompatibility of the ideal body shape will lead to dissatisfaction in his body.

Honigman and Castle (Bestiana, 2012) define body image as an individual's mental picture of body shape and body size, how the individual evaluates and perceives what he thinks and feels about his body size and shape and based on other people's assessments of him. The National Eating Disorders Association (Sari, 2012) defines body image as a person's feelings towards his body. 
This meansviews his body as positive, then his body image that if the individualis positive, whereas if the individual sees his body negatively, his body image is negative.

As stated by Rombe (2014), body image is an attitude or feeling of satisfaction and dissatisfaction that an individual has in his body so that it can lead to a positive and negative assessment of the individual himself. Cash and Smolak (2011) explain body image or more known as body image comes from the results of a person's psychological experience so that it affects perceptions, feelings, thoughts on physical appearance. Muth and Cash (1997) explain that body imageis a multidimensional construct consisting of cognition, emotion, perception and behavior related to physical attributes.Body image is not something static and always changing. The formation process is influenced by imagination, emotion, perception, mood, environment, and physical experience.

Banfield and McCabe (2002) explain thatbody image is a series of assessments of the body or physical appearance accompanied by anxiety such as the fear of being fat, the fear of being too thin , and also dissatisfaction with the body. Hamilton (2008) suggests that today's life is surrounded and filled with "perfect body image typeperfect body type" or the.Thebody image idealshown via the internet is not the same as thereal self individual's, it can make individuals dare to express themselves (Gonzalez \& Hancock, 2011).

Based on the explanation above, it can be concluded that body image is a description of body shape which includes size, shape, and appearance of the body itself. Body image is subjective, because it is influenced by social factors and social experiences of each individual that makes individuals feel satisfied or dissatisfied with body parts and overall physical appearance.

\subsubsection{Aspects of Body Image}

According to Cash \& Pruzinsky (2002), suggests five aspects of body image, among others:

a. Appearance evaluation (appearance evaluation)

Individuals assess their overall appearance, satisfied or not with appearance and measure attractive or not physical attractiveness which he has.

b. Appearance orientation (appearane orientation)

Individuals pay close attention to their appearance and improve their appearance with various planned efforts to improve their appearance.

c. Anxiety about being overweight (overweight preoccupation)

Individuals feel anxious and wary of body weight, go on a diet, also begin to regulate eating patterns in anticipation of weight gain.

d. Classification of body weight (self classified weight)

Individuals have their own perceptions of how the criteria and points of view of others in providing an assessment of the size of their body.

e. Satisfaction with body parts (body areas satisfaction)

Individual assessment of satisfaction or dissatisfaction with certain body parts specifically. For example on the face, hair, hips, as well as on the body as a whole. 


\subsubsection{Body Image Factors Body}

image is formed from the person's birth and lasts as long as the person lives. Many things can affect a body image person's, including the perception or judgment of others about one's own appearance. Some experts suggest that there are several factors that can affect a body image person's, while the factors that influence the development of body image are as follows:

1. Gender

In line with the development of an body image individual's, gender is one of the influencing factors. Dissatisfaction with the body is more common in women than men. In general, women feel dissatisfied with their body shape and cause the woman to have body image a negative. Women are usually more critical of their bodies both as a whole and on certain parts of their bodies than men. Men tend to view their bodies as functional and active in order to support activities. Women are more concerned about their bodies in terms of aesthetics. Thus, women have lower body image satisfaction than men.

\section{Parents}

According to Kearney and Cookie (Cash \& Pruzinsky, 2002), in some studies found that there is a relationship between attitudes and behavior of parents in respect body image of their ownwithaward body image for their children. Parents can influence the development of their body image child'sby choosing and commenting on their child's clothes and appearance, or by encouraging their child to look a certain way and avoid certain foods.

3. Interpersonal Relations

Dunn and Gokee (Cash \& Pruzinsky, 2002) explain that basically interpersonal relationships make an individual tend to compare himself with others and the feedback received affects his selfconcept this also includes feelings towards physical appearance. Rosen and colleagues (Cash, 1994). ) stated that feedback on the appearance and competence of peers and family in interpersonal relationships can affect the perspective and feelings about an individual's body.

Dun and Gooke (Cash \& Pruzinky, 2002) receiving feedback about their physical appearance means that someone develops a perception of how someone makes social comparisons which is one of the formation processes in self-assessment of physical attractiveness. Thoughts and feelings about the body stem from the reactions of others. In a developmental context, body image originates from interpersonal relationships. The emotional and thought development of the individual also contributes to how a person sees himself. Thus, how a person thinks and feels about his or her body can influence relationships and psychological characteristics. .

4. Mass Media

Tiggemann (Cash \& Pruzinsky, 2002) explains that the mass media has a significant role in shaping a person's perception of his body image. The media always shows someone who is considered ideal with predetermined criteria. This is recognized by media connoisseurs, so that the 
media increasingly plays a role in shaping one's perception of body image and perfect body image type, which makes women compare their bodies with the ideal body shown by the media.

High media consumption can affect consumers in a number of ways. The content of mass media shows often depicts the beauty standard of women with thin bodies, in this case it means that the level of thinness possessed by most women believes they are healthy people. The media also depicts the ideal body image for men to have a muscular body and a flat stomach. According to Longe (in Cash, 1994) body image can be influenced by external influences. Media sources such as TV, internet, and magazines often depict people closer to the generally accepted ideal body type than the average body image, in order to sell their products. As a result, people, especially children and young adults, are overly influenced and influenced. and are affected by depictions such as body image.

\subsection{Social Media Instagram}

\subsubsection{Definition of Social Media Social}

Media is an online media, where users can easily participate, share and create content including blogs, social networks, wikis, forums and virtual worlds. Social media serves as an intermediary tool that helps individuals to communicate with various parties in the world (Sikape, 2014). Boyd and Ellison (2008) define social media as a form of web-based service that allows individuals to create personal profiles, share information, and view and traverse the profiles of people registered within their range of connections. The researcher concludes that social media is an intermediary tool that is connected to the internet to interact with other people in various parts of the world using a cellphone or computer, so that communication is indirectly (non-face to face) or can be called the virtual world.

Karjaluoto (2008) revealed that the term social media describes a medium so that users can easily participate and contribute in the media. A common characteristic of social media loyalists is the openness of dialogue between users. The conclusion from the above description is that social media also provides and forms new ways of communicating. As is known, before the emergence and popularity of social media, most people communicated by way of SMS or telephone via cellphone. But now with social media, people tend to communicate via chat services or send messages via services available on social media.

\subsubsection{Definition of Instagram}

Instagram is a social media application that allows users to take photos and videos, apply digital filters (applying effects to photos) and share them on various social media including Instagram itself (Taqwa MI, 2018). shared will be posted on the feeds of other users who are your followers . The friendship system on Instagram uses the terms following and followers as on 
Twitter.Following means you follow users, while followers means other users who follow you. Furthermore, each user can interact by commenting and responding to likes on the shared photos (Tarigan, 2018).

Instagram comes from the understanding of the overall function of this application. The word "insta" comes from the word "instant", like the polaroid camera which at that time was better known as "instant photo". Instagram can also display photos instantly, like a polaroid in its display. As for the word "gram" comes from the word "telegram" which works to send information to other people quickly. Likewise with Instagram, which can upload photos using the internet network, so that the information you want to convey can be received quickly. Therefore Instagram is a combination of the words instant and telegram(Tarigan, 2018).

In Instagram social media, there are characters that cannot be eliminated in the consumption of content, namely celebgrams. Selebgram is an acronym forCelebrities Instagram. Celebrities themselves are people who have prominent profiles and have public appeal and everyday influence in the media (Rayan FM: 2004). The nickname celebgram is usually given to the personal account of someone who is famous on Instagram who has many fans or followers because the photos or videos he uploads are interesting and liked by many people. Sometimes the uploaded photos and videos become viral and are discussed by netizens a lot.

Celebrities often benefit from their popularity. Besides being able to become a public figure and get a lot of connections. Celebrities are tangible manifestations of various images or associations that are thought of by their followers.

The model or person who usually becomes a celebgram has several indicators:

a. Visibility (Possibility to be seen)

The characteristic visibility of a celebgram refers to how famous or he is known by the general public. This is because the expected response is to note

b. Credibility (Credibility)

Credibility reflect the perceptions of followers of the skills, knowledge, and relevant experience possessed by selebgram concerning content uploaded on social media instagramnya. The concept of celebrity credibility has long been known as an important element in determining whether someone wants to be a follower or not. Thus, the greater the expertise and trust that followers have, the more credible the celebrity will be.

\subsubsection{Features on Instagram}

Some of the features on Instagram according to Tarigan (2018: 51) are:

\section{Camera}

The camera feature allows Instagram users not only to upload photos from the gallery, but can also directly take photos or record moments with effects. the camera that is already on Instagram from within the application then the user can directly edit, give a caption newand share it.

2. Editor 
Editor is a feature that gives users the opportunity to polish photos taken through their device's camera. Here you will find 10 advanced editor tools to adjust exposure, contrast and saturation as easily as moving your finger. In the latest update, Instagram no longer requires square photos, but supports portrait and landscape options. Gives users flexibility when they want to share photos with a wider angle of view of the lens.

3. Tags and hashtags

This feature, like social networks in general, has a function to tag friends or group photos into one label. This feature makes it easier for users toexplore a trend or desired content or find other users.

\section{Caption}

Caption functions like a description, this is where the user can give a few words about the uploaded photo. The caption itself is a description box that is in every upload that we upload, the writing is usually accompanied by adding a hashtag.

5. Integration into social media

Instagram also allows users to share photos or videos to other social networks such as Facebook, Twitter, Tumblr and Flicrk. When tool thisis activated, every time a photo is shared,automatically Instagram willshare it to social networks that are already connected.

6. Instastory

Instastory is the latest feature from Instagram, which takes theformat snapchat where uploads will only last for 1 day with a maximum duration of 15 seconds.

\section{Explore}

feature that displays content viewed by the following or followers user's. As a social media used by the general public,certainly Instagram has several advantages and disadvantages. The following is a description of the advantages and disadvantages of Instagram.

\section{Results}

Based on research conducted on psychology students using Instagram, all subjects had an ideal self-image as desired, including an ideal body shape. Not realizing the ideal body shape they want will lead to feelings of dissatisfaction with their body. The evaluations they apply are based on specific criteria they have and are based on measurement references in the form of BMI and BMI. Evaluation of the body or physical appearance is not a static thing and is always changing because the formation process is based on physical experience, moods including the environment and emotions of an individual.

The level of a person's self-image is described based on how far the individual is satisfied with body parts and overall physical appearance. Dissatisfaction with body shape causes psychology students in this study to make efforts aimed at realizing the perfect body image type they desire. These efforts include doing sports activities, consuming beverages with certain ingredients to regulating diet and reducing calories that enter the body. 
Social media has a role in influencing the formation of body image. Perfect body image type or perfect body type is widely displayed on social media, including Instagram itself. In various contents, there are many displays of someone who is considered ideal with the criteria set even though in reality it is not in accordance with the real-self of the individual. According to Setiawati (2020) in her research, $46.3 \%$ of students tend to make appearance comparisons, and 14.8 students themselves often make comparisons on Instagram.

The consumption of psychology students' Instagram usage in this study played a role in shaping one's perception of body image and ideal appearance, which made women compare their bodies with the images shown by the media. This is in accordance with research that has been conducted on psychology students using Instagram who also compare themselves with the content they see. Tylka \& Sabik (2010) stated that the more often women compare their physique to the bodies of other women, the more dissatisfied they are with their bodies.

\section{CONLUSSION}

The level of a person's self-image is described based on how far the individual is satisfied with body parts and overall physical appearance. The five subjects classified their bodies negatively and thought that they were fat people. Dissatisfaction with body shape causes psychology students in this study to make efforts aimed at realizing the perfect body image type they desire. Each subject has anxiety about obesity and is very concerned about their portion and weight. The subjects also had different ways of anticipating weight gain.

Students who enjoy Instagram content sometimes compare themselves to the image they see through the media, resulting in negative thoughts and overthinking. In the various contents, there are many people who are considered ideal according to the criteria set even though in reality it is not in accordance with the real-self of the individual. This can be seen that the more subjects compare themselves, the more they feel dissatisfied with their bodies.

\section{REFERENCE}

Amalia, L. (2007). Citra Tubuh (body image) Remaja Perempuan. Jurnal Musawa. 5(4). Ponorogo .

Andarwati, I. (2016). Citra diri Ditinjau Dari Intensitas Penggunaan Media Jejaring Sosial Instagram Pada Siswa Kelas XI SMAN 9 Yogyakarta. Bimbingan dan Konseling Universitas Negeri Yogyakarta Edisi 3 Tahun Ke - 5. 
Aqromy, M. F. (2019). Hubungan Antara Kontrol Diri Dalam Memilih Konten dan Intensitas Penggunaan Media Sosial Instagram Pada Mahasiswa. SKRIPSI .

Arthur, S. R., \& Emily, S. R. (2010). Kamus Psikologi. Yogyakarta: Pustaka Pelajar.

Awallia, D.L. (2018). Pengaruh Testimoni Selebgram Endorsement Terhadap Minat Pembelian Pada Online Shop Melalui Media Sosial Instagram Mahasiswa Fakultas Syariah IAIN Ponorogo. SKRIPSI.

Burns, R. B. (1993). Konsep Diri: Teori Pengukuran, Perkembangan, Perilaku. Terjemahan Oleh Teddy.

Cash, T. (1994). Body Image Attitudes : Evaluation, Investment and Affect : Perceptual Motor Skills. Jounal Of Psychology, 1168 - 1170.

Creswell, J.W. (2015). Penelitian Kualitatif dan Desain Riset. Yogyakarta: Pustaka Belajar

Martanatasha, M.,\& Intan,P . (2019) Relasi Self Esteem dan Body Image Dalam Terpaan Media Sosial Instagram. Ultimacomm. Vol 11 No 2

Mufida, N. (2019). Hubungan Antara Body Image dan Kepercayaan Diri Pada Remaja Putri. SKRIPSI .

Mukhlis, A. (2013). Berpikir Positif Pada Ketidakpuasan Terhadap Citra Tubuh (Body Image Dissatisfaction). Jurnal Psikologi Islam. Vol 10, No 1

Metifa, S.,\& Yulianto,M. (2018). Fenomena Gaya Hidup Selebgram (Studi Fenomenologi Selebgram Awkarin). Interaksi Online 6. Jurnal Jurusan Komunikasi Universitas Diponegoro

Moloeng, L.J. (2018). Metodologi Penelitian Kualitatif. Bandung: PT Remaja Rosdakarya

Nasiha, N. F. (2017). Pengaruh Penggunaan Media Sosial Instagram Terhadap Citra Tubuh Mahasiswa Fakultas Ushuluddin Adab Dan Dakwah IAIN Ponorogo Tahun 2016. Dialogia, Vol. 15, No. 01 .

Nurfajri, A. P. (2017). HUbungan Antara Kebersyukuran dan Body Image Pada Remaja Putri. SKRIPSI .

Poerwandari E K. (2013). Pendekatan Kualitatif Untuk Penelitian Perilaku Manusia. Depok: Universitas Indonesia 
Rahmania, I. F. (2018). Hubungan Intensitas Melihat Instagram Terhadap Kepuasan Citra Tubuh. Studi Korelasi Pada Followers Wanita Akun @ millencyrus .

Rozika, L. A., \& Ramdhan, N. (2016). Hubungan antara Harga Diri dan Body Image . Gadjah Mada Journal Of Psychology, Vol.2, No. 3 , 172 - 183.

Royan, F. M. (2015). Marketing Selebrities. Jakarta: Raja Grafindo Persada

Setiawati, N. A. (2020). Hubungan Antara Perbandingan Sosial Dan Citra Tubuh Pada Mahasiswa Pengguna Media Sosial Instagram. SKRIPSI

Sugiyono. (2010). Memahami Penelitian Kualitatif. Bandung: Alfabeta

Sugiyono. (2016). Metode Penelitian Kuantitatif , Kualitatif dan R\&D. Bandung: Alfabeta

Tarigan, S. W. (2018). Perbedaan KOmunikasi Interpersonal Ditinjau Dari Intensitas Penggunaan Media Sosial Instagram Pada Remaja di Universitas Medan Area. SKRIPSI .

Taqwa, M I. (2018). Intensitas Penggunaan Media SosialInstagram Stories Dengan Kesehatan Mental. SKRIPSI

Thompson, J. K. (2000). Body Image, Eating Disorders, and Obesity. Washington: American Psychological Association.

Yin, R. K. 2004. "Studi Kasus Desain \& Metode. Jakarta: PT Grafindo Persada

Zakirah, D. M. (2018). Mahasiswa dan Instagram (Study Tentang Instagram Sebagai Sarana Membentuk Citra Diri Di Kalangan Mahasiswa Universita Airlangga. Jurnal S1 Sosiologi FISIP Universitas Airlangga . 